\title{
The use of Dried Orange Pulp for Feeding Meat Rabbits
}

\author{
H. S. Zeweil, S. M. Zahran, M. H. Ahmed, K. I. Kamel, W. M. Dosoky, \\ Yasmin El-Gendy and M. Bahr
}

Department of Animal and Fish Production, Faculty of Agriculture (Saba Basha),
University ofAlexandria, Alexandria, Egypt.
${ }^{*}$ Agriculture Research Center, Animal Production Research Institute, Cairo, Egypt.
Corresponding author: hszeweil@yahoo.com

ABSTRACT : This study aimed to evaluate the growth performance, carcass traits and digestibility coefficients of growing rabbits fed different levels of orange pulp. Orange pulp was replaced for barley in the basal diet at 4 levels $(0,7.5,15$ and $30 \%)$. A total number of 36 growing V-line rabbits at 7 weeks of age, with an average initial live body weight of $760.9 \pm 33.9$ $\mathrm{g}$, were individually weighed and randomly assigned individually into four groups in a completely randomized design representing the four experimental groups. Each group was divided into three replicates of three rabbits each. All rabbits were kept under the same management and hygienic conditions and were housed in metal battery cages supplied with separated feeders. Diets were offered ad-libitum and fresh water was available all times from automatic nipple drinkers. The experimental period lasted for 42 days. The obtained results showed that barley replacement levels by dried orange pulp up to $30 \%$ showed insignificant differences on the performance and carcass traits of growing rabbits when compared with the control diet. Also, there were insignificant differences in dry matter, organic matter, crude protein, crude fiber, and nitrogen free extract digestibility among the experimental diets and control diet, however, the digestibility coefficient of ether extract was recorded highest $(P \leq 0.05)$ values for $7.5,15$ and 30 $\%$ substitution level of orange pulp when compared to the control diet. The nitrogen free extract digestibility recorded the lowest value with $30 \%$ substitution of orange pulp when compared to the control diet and other replacement levels of barley by dried orange pulp; however, the difference was not significant. Metabolizable energy (ME), total digestible nutrients (TDN) and digestible crude protein (DCP) recorded insignificant difference among control diet and 7.5, 15, and $30 \%$ substitution levels of orange pulp. It could be concluded that barley replacement levels by dried orange pulp up to $30 \%$ had no negative effects on growth performance, carcass and digestibility coefficients of nutrients.

Key words: Rabbits performance, orange pulp, carcass traits, digestibility

\section{INTRODUCTION}

The corn and barley considers main energy source in the rabbits and poultry diets. The available of them depends on some factors such as import of feedstuffs and uses it in some industrial as ethanol production. The agroindustrial processing was resulted some wastes as vegetable and fruit byproducts. The fruit byproducts use as energy source in animal feed (Crickenberger, 1991) and these by-products are economical and environmentally sound way for food processors to reduce waste discharges and cut waste management cost. Selling by-products can also produce additional revenue. The active antioxidant compounds are flavonoids, isoflavones, flavones, anthocyanins, coumarins, lignans, catechins and isocatechins. In addition, some compounds found in natural foods such as vitamins $C$ and $E, \beta$-carotene and $\alpha$-tocopherol are known to possess antioxidant potential (Prior, 2003). Flavonoids is good for keeping human and animals healthy. Pectin is a kind for carbohydrate gel, a component of plant cell wall. And thus it has high water

Vol. 20(1), 2015 
absorption property and can use for treating diarrhea and its viscosity has significant health benefits. Citrus pulp contains flavonoids and pectin. Larrauri et al. (1996) reported that flavonoids which play role in reducing cholesterol because the structure of flavonoids contains numerous $\mathrm{OH}$ group which can supply $\mathrm{H}$ atoms to quench free radical, making it a strong antioxidant and antitumor activity meanwhile, may play a role in cancer, heart disease, circulation and Alzhemers' disease (Shahelian, 2005). Ascorbic acid is antioxidant act (Marcy et al., 1989). Oluremi et al. (2006) reported that content of Sweet Orange Rind for vitamin C was $3.88 \mathrm{mg} / 100 \mathrm{~g}$ vs zero $\mathrm{mg} / 100 \mathrm{~g}$ for maize or barley. Hon et al. (2009) reported that sweet orange fruit pulp meal can be used as replacement feedstuff for maize in the ration of growing rabbits up to $20 \%$. The main objective of present study was to evaluate the nutrient value of orange pulp as non-conventional sources for energy in growing rabbits feeding.

\section{MATERIALS AND METHODS}

Thirty-six healthy growing $\mathrm{V}$-line rabbits of both sexes with initial weights of $760.9 \pm 33.9 \mathrm{~g}$ were used for the study. The rabbits were randomly allocated to four treatments groups of 9 rabbits each. Each treatment was further subdivided into 3 replicates of 3 rabbits. The rabbits were weighed at the beginning of the experiment to obtain their initial body weight and subsequently biweekly. The rabbits were housed in galvanized wire cages with flat deck (50 x 50 x 40 $\mathrm{cm}$ ) three rabbits in each cage, in a well-ventilated building. A cycle of 16 hours of light and 8 hours of dark were provided throughout the experiment. Orange fruit pulp was collected fresh from Edfina Factory for nutritional products in Alexandria city, Alexandria governorate, Egypt. The orange pulp was sun dried for $48 \mathrm{~h}$ on concrete floor until it became crispy. It was grinded and three samples of it were taken for proximate chemical analysis according to AOAC (1995). Rabbits were fed experimental diets in a pellet form. Feed and water were provided ad libitum throughout the experimental period from 7 to 13 weeks of age by using high standard hygiene and careful management. Four pelleted experimental diets were formulated. Dried orange pulp was replaced for barley in the basal diet, some modifications were done in the composition of the basal diets to make the four experimental diets isonitrogenous and isoenergetic containing approximately $17 \% \mathrm{CP}$ and $2570 \mathrm{Kcal} / \mathrm{kg} \mathrm{DE}$, at 4 levels $(0,7.5,15$ and $30 \%$ ). The control basal experimental diet and all experimental diets were formulated to cover all essential nutrient requirements for growing rabbits according to NRC (1977).

Ingredients and chemical composition of the experimental diets are shown in Table 1. At 13 weeks blood samples were collected from 3 rabbits from each treatment from the marginal ear vein in heparinzed tubes. Plasma were obtained by blood samples centrifugation for $20 \mathrm{~min}$. at $4000 \mathrm{rpm}$ and stored at $-20^{\circ} \mathrm{C}$ in Eppendorf tubes until analysis. All tests; total lipids, total cholesterol, low density lipoprotein, high density lipoprotein, creatinine and uric acid, total antioxidant capacity (TAC) and lipid peroxide Malondialdehyde (MDA) were carried out using the commercial kits produced by Human (Max-PlanckRing 21-D-65205 Wiesbaden, Germany). At the end of growing period (13

Vol. 20(1), 2015 
weeks of age), three rabbits of 13 weeks of age were taken randomly from each treatment, fasted for $12 \mathrm{hrs,} \mathrm{weighed,} \mathrm{slaughtered} \mathrm{by} \mathrm{the} \mathrm{cut-throat}$ method and dressed to determine the percentage of dressing, head, fur and the relative visceral organs. All traits were calculated as percentage of the preslaughter weight. At 13 weeks of age, twelve male rabbits (three rabbits from each treatment) were randomly taken after the termination of fattening trial. Rabbits within each treatment were randomly housed individually in metabolic cages that allowed separation of feces and urine. A preliminary period of 7 days was followed by five days for measurements of actual consumed feed, feces and collection of feaces and urine. The rabbits were fed twice daily at 8 a.m. and 4 p.m. Water was available all time. Feces of each rabbit was collected quantitatively once a day before offering the morning meal at 8 a.m. Samples $(100 \%)$ of daily feces of each rabbit were stored at $-200 \mathrm{C}$. The five days combined collection fecal samples were kept for routine analysis. Fecal samples were oven dried at $600 \mathrm{C}$ for $48 \mathrm{~h}$ (partial drying) then ground through a $1 \mathrm{~mm}$ screen on a wiley mill grinder. Samples were composite per treatment per animal for analysis. Representative samples of feed offered and feces of each rabbit were chemically analyzed for determinations of dry matter (DM), organic matter (OM), crude protein (CP), ether extract (EE), crude fiber (CF) and ash which were carried out according to A.O.A.C. (1995) methods. Nitrogen free extract (NFE) was determined by difference. Data were analyzed using one-way ANOVA of GLM procedure of SAS $\AA^{\circ}$ (SAS Institute, 2000). Significant differences between means were detected using mew Duncan multiple range test (Duncan, 1955).

\section{RESULTS AND DISCUSSIONS}

Results presented in Table 2 showed the proximate analysis of dried orange pulp and barley. Data showed that dry matter, organic matter and nitrogen free extract contents were nearly equals. While, the crude protein of dried orange pulp in the present study was lower than crude protein of barley by $38.0 \%$. Also, it was found that crude fiber, ether extract and ash contents of dried orange pulp were higher than those in barley by $69.2,26.1$ and $23.2 \%$, respectively.

The obtained results on organic matter (OM) of dried orange pulp was found to be higher by $5.8 \%$ than those obtained by Lemoet al. (1984) who found that the values of OM of dried orange pulp was 90.57. Also, ether extract (EE) contents in dried orange pulp were higher by $51.9 \%$ than those obtained by Oluremiet al. (2007) who found that EE of dried orange pulp was $2.35 \%$. In contrast, crude protein (CP) of dried orange pulp in the present study was lower than those obtained by Madrid et al. (2002), Oluremiet al. (2006 and 2007) who reported that CP content of dried orange pulp ranged from 9.3 to $11.4 \%$. Also, ash content in the present study was decreased by $12.2 \%$ than those obtained by Ibrahim et al. (2011) which recorded value of $5.02 \%$. The proximate composition of dried orange pulp shows that it can be nutritionally evaluated as a possible substitute for barley in rabbit diets. The energy content of dried orange pulp was $2648 \mathrm{Kcal} / \mathrm{kg}$ as compared to energy content of barley 2761 
$\mathrm{Kcal} / \mathrm{kg}$ (Table 2) which suggests that this dried orange pulp can be classified as energy feed. Its high crude fiber (CF) content (9.05\%) may be an advantage in rabbit nutrition since this livestock species requires a higher dietary crude fiber (minimum requirement of $9 \%$ ) recommended by Spreadbury and Davidson (1978) than poultry and swine. The results presented by Hon et al. (2009) showed that the crude fiber was $9.68 \%$, fractions of dried orange pulp contain $3.28 \%$ acid detergent lignin (ADL). This indicated that the fiber component of dried orange pulp contains more of digestible carbohydrates than indigestible.

The average live body weights of growing rabbits as affected by different levels of dried orange pulp under hot summer conditions are presented in Table 3 . It is clearly shown that no significant differences in body weight could be detected in initial body weight at 7 weeks of age. From 7 weeks of age and up to the end of the growing period at 13 weeks of age, non-significant differences were observed. Rabbits reared under stressful summer conditions and fed diets containing different levels of dried orange pulp had the nearly the same body weight values as compared with those fed control diet throughout the whole experimental period. Insignificant progressive increases in body weight with the increases of barley replacement levels by dried orange pulp up to $15 \%$ as compared to the control group or with the highest level of substitution (30\%). Barley replacement levels by dried orange pulp at 7.5 and $15 \%$ increased live body weight by $3.2 \%$ as compared with the control group; however, insignificant decrease in live body weight was obtained with $30 \%$ replacement level reached to $1.5 \%$ as compared with the control group. The significant improvement in live body weight of dried orange pulp treated groups may be due to the anabolism of animal (Abo-El-Ezzet al., 1984). It was noticed that daily weight gain of rabbits given barley replacement levels by dried orange pulp up to $15 \%$ non-significantly improved daily weight gain by $4.6 \%$ as compared with the heat stressed control group. On the other hand, the high replacement level (30\%) resulted in non-significant deterioration reached to 2.1 $\%$ from control group.

The results presented in Table 3 showed that the improvement in daily weight gain was due to the insignificant improvements in feed conversion ratio compared with the control group, and may be due to the biological function of dried orange pulp which have some extracts such as polyphenols, anthocyanine and hydrolysable tannine which act as antimicrobial and cause sterilization of gastrointestinal tract (Abdel-Azeem, 2005), or to tannin (one component of orange pulp) affect by reducing intestine movement which may lead to better nutrients absorption, which is reflected on body weight gain (Ismail, 2003).

Results presented in Table 3 showed insignificant effect of dried orange pulp on daily feed intake as compared to the control group. In addition, data in Table 3 showed that there was a non-significant variation in feed conversion ratio, the major target of producers. It is noticed that heat stressed control rabbits had the worst feed conversion values during the whole experimental period. Feed conversion ratios were insignificantly improved by dried orange pulp up to $15 \%$ barley replacement in rabbit diets, with one exception since the

Vol. 20(1), 2015 
group received high level of dried orange pulp showed insignificant deterioration in feed conversion ratio as compared to the control group or the other experimental groups. Also, it was observed that rabbits fed on $7.5 \%$ dried orange pulp instead of barley had the best feed conversion ratio. Dried orange pulp at 7.5 and $15 \%$ barley replacement insignificantly improved feed conversion ratio by 6.1 and $1.7 \%$ as compared with control group. Digestive disorders of growing rabbits were prevented by dried orange pulp, moreover severity of diarrhea was not observed by orange pulp inclusion in the diet. But generally, it was observed that no mortality was recorded during the feeding trial. This suggests that, up to $30 \%$ barley replacement by dried orange pulp did have any adverse effect on the rabbits. They did not show any signs of distress. This shows that dried orange pulp up to $30 \%$ barley replacement in rabbit diets can be used as an alternative dietary energy feed resource. The same results were obtained by Hon et al. (2009) on growing rabbits. The antioxidant capacity of citrus was correlated both to vitamin $\mathrm{C}$ and phenolics. Aside from citrus pulps, the peels are also good sources of bioactive compounds and minerals, and can be explored for their health promoting values in food products (Barros et al., 2012).

Including dried orange pulp instead of barley in the rabbit diets did not affect carcass traits as compared to the control group (Table 3). No significant differences were observed in dressed weight percent and organs relative weight. Results of dressed weight were in harmony with final live body weight. Insignificant differences were detected in digestibility coefficients of dry matter, organic matter, crude protein, crude fiber and nitrogen free extract; however, significant improvements in digestibility coefficients of ether extract were recorded with different levels of orange pulp replacement as compared with the control group. Also, digestible Energy (DE), total digestible nutrients (TDN) and digestible crude protein (DCP) recorded insignificant difference among control diet and $7.5,15$, and $30 \%$ substitution levels of orange pulp.

Conclusively, the result of this study have shown that up to $30 \%$ dietary barley in rabbit diet can be replaced with sun dried orange pulp without negative effects on the performance of rabbits. As a high energy source like barley, its inclusion in rabbit feed formulation would help to reduce the cost of feed. It is therefore, suggested that its practical abundance should be exploited as a significant leap to reduce the high demand on barley, its accompanying high cost and its direct effect on the cost of finished table meat product. 
Table (1): Composition and chemical analyses (\%) of the xperimental diets (as fed)

\begin{tabular}{|c|c|c|c|c|}
\hline \multirow{2}{*}{ Ingredients (\%) } & \multirow{2}{*}{ Control } & \multicolumn{3}{|c|}{ Orange pulp ( \%) } \\
\hline & & 7.5 & 15 & 30 \\
\hline Berseem hay & 30.20 & 29.93 & 29.85 & 29.60 \\
\hline Barley & 20.00 & 18.50 & 17.00 & 14.00 \\
\hline Orange pulp & ---- & 1.500 & 3.000 & 6.000 \\
\hline Corn yellow & 14.80 & 15.00 & 15.00 & 15.00 \\
\hline Wheat bran & 10.00 & 10.00 & 10.00 & 10.00 \\
\hline Soybean meal (44\%) & 19.60 & 19.67 & 19.75 & 20.00 \\
\hline Molasses & 3.000 & 3.000 & 3.000 & 3.000 \\
\hline Limestone & 1.000 & 1.000 & 1.000 & 1.000 \\
\hline Di-calcium-Phosphate & 0.300 & 0.300 & 0.300 & 0.300 \\
\hline Salt & 0.500 & 0.500 & 0.500 & 0.500 \\
\hline Vit. and min. mix. & 0.300 & 0.300 & 0.300 & 0.300 \\
\hline Lysine & 0.150 & 0.150 & 0.150 & 0.150 \\
\hline Methionine & 0.150 & 0.150 & 0.150 & 0.150 \\
\hline Total Chemical analyses(\%) & 100.0 & 100.0 & 100.0 & 100.0 \\
\hline Dry matter & 89.19 & 89.11 & 89.21 & 89.13 \\
\hline Organic matter & 81.56 & 81.41 & 81.54 & 81.36 \\
\hline Crude protein ( CP ) & 17.20 & 17.18 & 17.17 & 17.11 \\
\hline Crude fiber ( CF ) & 11.34 & 11.39 & 11.41 & 11.51 \\
\hline Ether Extract (EE) & 2.800 & 2.82 & 2.82 & 2.83 \\
\hline Ash & 7.630 & 7.70 & 7.67 & 7.77 \\
\hline NFE & 50.22 & 50.02 & 50.14 & 49.91 \\
\hline NDF & 36.37 & 36.41 & 36.42 & 36.49 \\
\hline DE (Kcal / kg) & 2574.02 & 2572.4 & 2571.8 & 2568.5 \\
\hline
\end{tabular}

$\mathrm{NFE}=$ Crude protein + Crude fiber + Ether Extract-Dry matter

Digestible energy (DE) of the experimental diets was calculated according to the equation described by Cheekeet al. (1987) as follows: DE $(\mathrm{K} / \mathrm{kg})=4.36-0.0491 \times N D F \%$ $\mathrm{NDF}=28.924+0.657 \times \mathrm{CF} \%$ 
Table (2): Proximate chemical composition of dried orange pulp and barley (on dry matter basis).

\begin{tabular}{lcc}
\hline \multicolumn{1}{c}{ Items } & Dried orange pulp & Barley \\
\hline Dry matter, \% & 92.82 & 91.60 \\
Organic matter, \% & 95.83 & 96.60 \\
Crude protein, \% & 7.93 & 12.80 \\
Crude fiber, \% & 9.05 & 5.35 \\
Ether extract, \% & 3.57 & 2.83 \\
Ash, \% & 4.41 & 3.58 \\
Calcium, \% & 1.10 & 0.03 \\
Phosphorus, \% & 0.45 & 0.36 \\
NFE & 67.86 & 67.70 \\
NDF & 34.87 & 28.00 \\
DE (Kcal / kg) & 2648 & 2761 \\
\hline
\end{tabular}

Digestible energy (DE) of the tested materials was calculated according to the equation described by Cheekeet al. (1987) as follows: DE $(\mathrm{K} / \mathrm{kg})=4.36-0.0491 \times \mathrm{NDF} \% \mathrm{NDF}=$ $28.924+0.657 \times$ CF\%

Table (3): Growth performance, carcass traits, digestibility coefficients of nutrients and nutritive values of V-line rabbits fed on the experimental diets.

\begin{tabular}{|c|c|c|c|c|}
\hline \multirow{2}{*}{ Parameters } & \multirow{2}{*}{ Control } & \multicolumn{3}{|c|}{ Orange pulp ( $\%$ ) } \\
\hline & & 7.5 & 15 & 30 \\
\hline \multicolumn{5}{|l|}{ Growth performance: } \\
\hline Initial body weight, $\mathrm{g}$ & $760.1 \pm 50.1$ & $761.7 \pm 39.5$ & $763.3 \pm 26.1$ & $758.3 \pm 33.7$ \\
\hline Final body weight, $\mathrm{g}$ & $2339.4 \pm 88.0$ & $2413.3 \pm 67.2$ & $2415.0 \pm 82.9$ & $2304.4 \pm 75.3$ \\
\hline Daily weight gain, $g$ & $28.2 \pm 1.5$ & $29.5 \pm 0.9$ & $29.5 \pm 1.1$ & $27.6 \pm 1.0$ \\
\hline Daily feed intake, $\mathbf{g}$ & $97.2 \pm 1.0^{\mathrm{ab}}$ & $95.3 \pm 1.1^{b}$ & $99.7 \pm 3.0^{\mathrm{a}}$ & $96.3 \pm 2.1^{\mathrm{ab}}$ \\
\hline \multicolumn{5}{|l|}{ Digestibility coefficients: } \\
\hline Dry matter, \% & $66.74 \pm 0.34$ & $66.02 \pm 0.95$ & $65.72 \pm 0.48$ & $65.20 \pm 0.55$ \\
\hline Organic matter, \% & $65.4 \pm 2.8$ & $65.6 \pm 1.1$ & $64.9 \pm 1.9$ & $64.5 \pm 3.0$ \\
\hline Crude protein, \% & $76.6 \pm 2.3$ & $76.9 \pm 1.9$ & $76.4 \pm 77.2$ & $77.2 \pm 3.5$ \\
\hline Ether extract, \% & $56.7 \pm 3.7^{c}$ & $63.8 \pm 2.1^{\mathrm{b}}$ & $65.0 \pm 1.9^{b}$ & $67.0 \pm 2.0^{\mathrm{a}}$ \\
\hline Crude fiber, $\%$ & $30.8 \pm 6.3$ & $33.9 \pm 1.9$ & $32.8 \pm 4.1$ & $34.9 \pm 6.6$ \\
\hline \multicolumn{5}{|l|}{ Nutritive values: } \\
\hline TDN,\% & $54.8 \pm 2.4$ & $55.8 \pm 1.0$ & $56.1 \pm 0.9$ & $55.0 \pm 2.6$ \\
\hline DCP,\% & $13.2 \pm 0.4$ & $13.2 \pm 0.3$ & $13.1 \pm 0.4$ & $13.3 \pm 0.6$ \\
\hline$M E(K c a l / k g)$ & $2293.2 \pm 101.8$ & $2335.8 \pm 40.7$ & $2348.5 \pm 39.7$ & $2300.8 \pm 110.3$ \\
\hline \multicolumn{5}{|l|}{ Carcass traits: } \\
\hline Dressed weight, \% & $59.7 \pm 0.5$ & $60.1 \pm 0.8$ & $59.6 \pm 0.4$ & $60.6 \pm 0.6$ \\
\hline Heart, \% & $0.57 \pm 0.02$ & $0.48 \pm 0.05$ & $0.64 \pm 0.02$ & $0.51 \pm 0.05$ \\
\hline Liver, \% & $5.16 \pm 0.58$ & $5.24 \pm 0.48$ & $6.11 \pm 0.50$ & $4.85 \pm 0.16$ \\
\hline Spleen, \% & $0.05 \pm 0.01$ & $0.06 \pm 0.01$ & $0.05 \pm 0.00$ & $0.05 \pm 0.00$ \\
\hline Head, \% & $9.6 \pm 0.4$ & $9.2 \pm 0.3$ & $9.0 \pm 0.5$ & $9.0 \pm 0.3$ \\
\hline Fur, \% & $13.7 \pm 0.8$ & $13.9 \pm 0.5$ & $14.2 \pm 0.2$ & $13.7 \pm 0.6$ \\
\hline \multicolumn{5}{|c|}{$\begin{array}{l}\text { a-c Means in the same row bearing different superscripts differ significantly }(p \leq 0.05 \\
\text { TDN }=\text { Total digestible nutrients DCP Digestible crude protein } M E=\text { Metabolisable } \\
\text { energy, ME was calculated according to Forbes }(1985) . M E=T D N \times 41.85 \text {. }\end{array}$} \\
\hline
\end{tabular}

Vol. 20(1), 2015 


\section{REFERENCES}

Abdel-Azeem, Noha M. (2005). Effect of some organic components on rabbits productive efficiency. M. Sci. Thesis, Fac. Agric., Cairo, Egypt.

Abo-El-Ezz, Z., M. H. Salem, G. A. Abd El-Fattah and A. M. Yassen (1984). Effect of exposure to direct solar radiation on body weight, thermoregulation and reproductive efficiency in the male rabbit. In: Proceedings of 1st Egyptian-British Confer Noutyence on Animal and Poultry Production, Zagazig University, Egypt, 1: 119-135.

AOAC (1995). Official Methods of Analysis, 15th Ed. 1995. Association of Official Analytical Chemist, Washington, DC, USA.

Barros, Helena, R. M., Ferrgira, Tania, A. P. C. and Genovese, Maria, J. (2012). Antioxidant capacity and mineral content of pulp and peel from commercial cultivars of citrus from Brazil. Food chemistry,134: 18921898.

Cheeke, P.R. (1987). Rabbit feeding and nutrition. Academic press, Orlando, Florida, USA., pp: 376.

Crickenberger, R.G. (1991). Using food processing byproducts for animal feed, Pollution prevention pays in food processing. North Carolina Cooperative extension service.

Duncan, D.B. (1955). Multiple range and multiple F test. Biometrics, 11: 1-42.

Forbes, J.M. (1984). The effect of sex hormones, pregnancy, and lactation on digestion metabolism, and voluntary food intake. pp. 420-435. In: Milligan L P, Grovum W L and Dobson A (eds). Control of Digestion and Metabolism in Ruminants. Prentice-Hall, New ork.

Hon, F.M., O.I. Oluremi and F.O.I. Anugwa (2009). Effect of dried sweet orange (Citrus sinensis) fruit pulp meal on the growth performance of rabbits. Pak. J. Nutr., 8: 1150-1155.

Ibrahim,M. R., H.M. El-Banna, I.I. Omara and Marwa A. Suliman (2011). Evaluation of Nutritive Value of Some Citrus Pulp as Feedstuffs in Rabbit Diets. Pakistan Journal of Nutrition, 10 (7): 667-674.

Ismail, H. A. M. (2003). Effect of certain medicinal plants on the performance of growing rabbits. M. Sc. Cairo university.

Larrauri, J.A., P. Ruperez, L. Bravo and F.S. Calixto (1996). High dietary fiber powders from orange and lime peels: Associated polyphenols and antioxidant capacity. Food Res. Int., 29: 757-762.

Lemo, G., M.L. Alicata, A. Bonanno and M. Bacchi (1984).Trials on the use of dried orange and lemon pulp for feeding meat rabbits. Coniglicoltura, 21:53-58.

Madrid, J., M.D. Megias and F. Herandez (2002). In-vitro determination of ruminal dry matter and cell wall degradation and production of fermentation endproducts of various by-products. Anim. Res., 51: 189199.

Marcy, J.E., A.P. Hansen and T.R. Graumilch (1989). Effect of storage temperature on the stability of aseptically packaged concentrated orange juice and concentrated orange drink. J. Food Sci., 54: 227. 
National Research Council (NRC). (1977). Nutrient requirements of domestic animals. Nutrient Requirement of Rabbits. USA National Academy of Science. Washington, D.C.

Oluremi, O.I.A., I.A. Andrew and J. Ngi (2007). Evaluation of nutritive polential of the peels of some citrus fruit varieties as feeding stuffs in livestock production. Pak. J. Nutr., 6: 653-656.

Oluremi, O.I.A., V.O. Ojighen and E.H. Ejembi (2006). The nutritive potentials of sweet orange (Citrus sinensis) rind in broiler production. Int. J. Poult. Sci., 5: 613-617.

Prior, R.L. ( 2003). Fruit and vegetables in the prevention of cellular oxidative damage. Am. J. Clin. Nutr., 78: 570S-578S.

SAS, Institute Inc. (2000). User's Guide: Statistics, Version 8.1. SAS Institute Inc. Cary, NC.

Shahelian, R.M.D. (2005). Decreased pro-inflammatory cytokine production by LPS-stimulated PBMC upon in vitro incubation with the flavonoids apigenin, luteolin or chrysin, due to selective elimination of monocytes/ macrophages. BiochemPharmacol., 69: 241-248.

Spreadbury, D. and J. Davidson (1978). A study of the need for crude fibre by the growing NewZealand white rabbit. J. Sci. Food and Agric., 29: 640648. 
الملخص العربي

أستخدام مخلفات البرتقال فى تغذية أرانب التسمين

حسن زويل ، سليمان زهران ، محمد حسن ، كامل ابراهيم** ، وليد دسوقى ، ياسمين مؤمن ،

$$
\begin{aligned}
& \text { موسىى بحر } \\
& \text { قسم الانتاج الحيواني والسمكى - كلية الزراعة (سابا باشا) - جامعة الاسكندرية - مصر }
\end{aligned}
$$

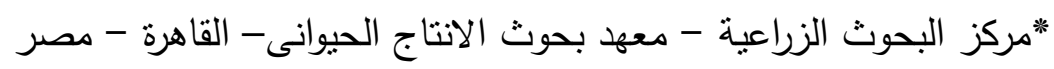

تهدف الدراسة الحالية لتقييم أداء النمو ، صفات الذبيحة ، معاملات هضم العناصر الغذائية فى الأرانب النامية

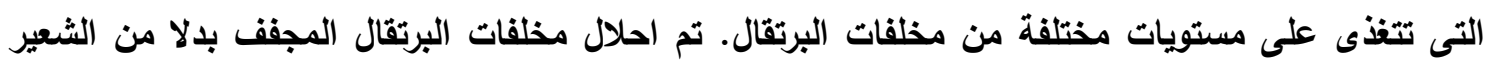
عند أربعة مستويات من الاحلال (صفر ، 7.5 ، 15 ، 30 \% \%) ـ أستخدم 36 أرنب نامى من نوع عمر 4 أسابيع بمتوسط وزن ابتدائى 760.9 جم تم وزنها وتوزيعها عشوائيا على أريع مجاميع فى تصميم

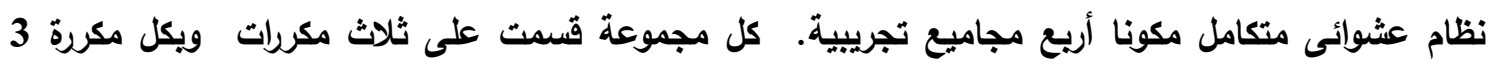

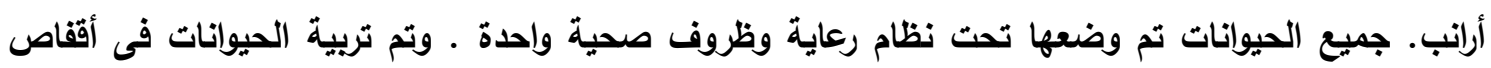
معدنية مزودة بغذايات منفصلة بكل قفص ـ تم تقديم العليقة بصفة دائمة وكان ماء الثرب متوفر باستمرار باستخدام حلمات الثرب. وقد أستمرت التجرية لمدة 42 يوم . وكانت أهم النتائج المتحصل علئه وليهات أنه يمكن

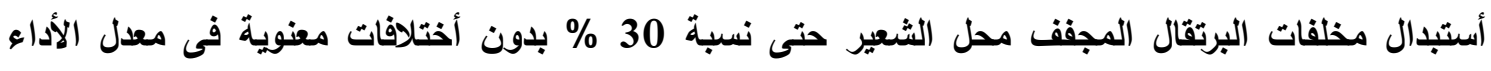

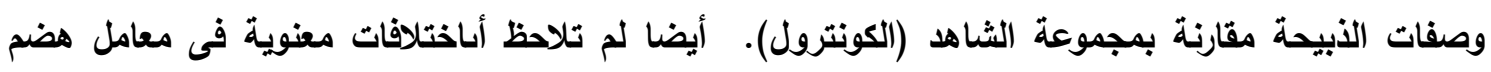

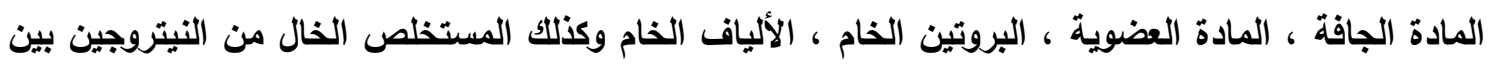
المجاميع التجريبية ومجموعة الثاهد. بينما وجد أن معامل هضم المستخلص الايثيرى كان الأعلى معنويا عند الأل نسب أستبدال 7.5 ، 15 ، 30 \% مقارنة مع مجموعة الشاهد. سجل معامل هضم المستخلص الخال من النيتروجين أقل قيمة مع نسبة أستبدال 30 \% مقارنة مع مجموعة الثاهد والمجاميع التجريبية الأخرى ولكن

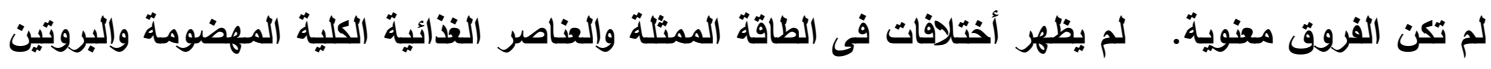

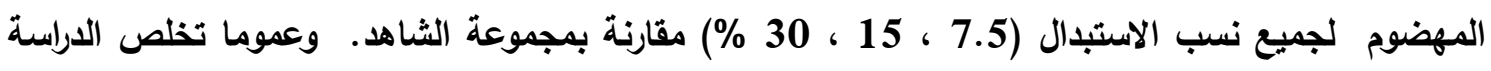

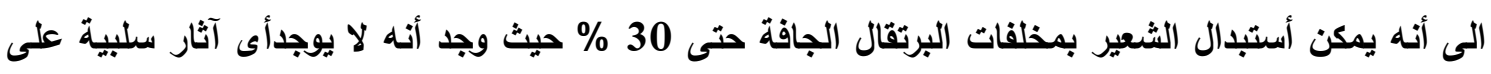
معدلات أداء الأرانب والذبيحة ومعاملات هضم العناصر الغذائية . 